\title{
PENGOLAHAN DATA LANDSAT 8 UNTUK EKSTRAKSI OBJEK DI PERMUKAAN LAUT
}

\author{
(Processing of Landsat 8 for Extracting Objects on the Sea Surface)
}

\author{
Tri Muji Susantoro ${ }^{1}$ dan Ketut Wikantika ${ }^{2}$ \\ ${ }^{1}$ Bidang Penginderaan Jauh PPPTMGB LEMIGAS \\ ${ }^{2}$ Kelompok Keahlian Inderaja dan SIG, Fakultas Ilmu dan Teknologi Kebumian-ITB \\ Jl. Ciledung Raya Kav.109 Cipulir, Kebayoran Lama, Jakarta Selatan-12230 Indonesia \\ E-mail: trimujis@lemigas.esdm.go.id
}

Diterima (received): 15 Juni 2015; Direvisi (revised): 30 Juli 2015; Disetujui untuk dipublikasikan (accepted): 1 September 2015

\begin{abstract}
ABSTRAK
Kenampakan objek di permukaan laut seperti kapal, bagan, platform migas dan lainnya secara umum mudah dipetakan menggunakan data citra satelit resolusi tinggi. Akan tetapi, harga citra satelit resolusi tinggi tersebut relatif lebih mahal. Penggunaan citra satelit resolusi menengah dan regional secara umum hanya untuk pemetaan permukaan laut masih didominasi untuk pemetaan kondisi fisik dan kimia air laut. Penelitian ini bertujuan untuk mengolah data Landsat 8 dalam rangka mengidentifikasi objek di permukaan laut. Berdasarkan hasil kajian objek di laut seperti kapal yang sandar di Pelabuhan Tanjung Emas, Semarang, kapal yang bergerak di Utara Delta Wulan dan bagan tancap di perairan Jepara dapat diidentifikasi menggunakan NDVI dan penisbahan saluran ((SWIR-RED)/(SWIR+RED)). Kenampakan kapal tampak lebih baik menggunakan NDVI dan penisbahan saluran ((SWIR-RED)/(SWIR+RED)) dibandingkan pada citra komposit warna dengan kombinasi band 653 (RGB). Kapal yang bergerak terlihat jelas dengan buih gelombang dibelakangnya, sedangkan pada citra komposit warna dengan kombinasi band 653 (RGB), buih gelombang tidak dapat dilihat. Demikian juga dengan bagan tancap yang tidak terlihat pada citra komposit warna dengan kombinasi band 653 (RGB). Namun demikian bagan tancap dapat diidentifikasi dengan jelas pada NDVI dan penisbahan saluran ((SWIR-RED)/(SWIR +RED)). Kemampuan Landsat 8 untuk memetakan objek di laut dengan baik ini, dapat dimanfaatkan secara optimal untuk perencanaan kegiatan di bidang migas dan peluang mencari kapal yang hilang ataupun untuk monitoring daerah rawan illegal fishing.
\end{abstract}

Kata kunci: Landsat 8, kapal, pelabuhan, bagan tancap, NDVI, penisbahan saluran, RGB

\section{ABSTRACT}

The appearance of the object on the sea surface like a ship, charts, and other oil and gas platforms are generally easily mapped using high-resolution satellite imagery data. However, the prices of high-resolution satellite images are relatively expensive. The use of medium resolution satellite imagery and regional general for mapping the sea surface is still dominated for mapping the physical and chemical conditions of seawater. The objective of this research is conducting a processing of Landsat 8 data for identifying objects on the sea surface. Based on the results, objects on the sea, such as ship that is docked at Tanjung Emas Harbour, Semarang and moving ship in North Wulan Delta, Demak, as well as bagan at Jepara sea can be identified using NDVI and Rationing band ((SWIR-RED)/(SWIR +RED)). The appearance of ship is better identified using NDVI and Rationing band ((SWIR-RED)/(SWIR +RED)) than on the composite imageries using combination bands of 653 (RGB). The moving ship seen more clearly with ripple wave in the backside, whereas its cannot be seen in the composite imageries using combination bands of 653 (RGB). Similarly, bagan cannot be seen in the composite imageries using combination bands of 653 (RGB). However, bagan can be identified clearly using NDVI and rationing band ((SWIR-RED)/(SWIR +RED)). Landsat 8 Ability to map the object in the sea with this good, can be used optimally for planning activities in the field of oil and gas and the opportunities to look for the missing ship or for monitoring areas prone to illegal fishing.

Keywords: Landsat 8, ship, harbour, bagan, NDVI, rationing band, RGB

\section{PENDAHULUAN}

Kenampakan objek di permukaan laut dibedakan menjadi dua bagian, yaitu kenampakan objek yang bersifat tetap dan bergerak. Kenampakan yang bersifat tetap misalnya bagan tancap, sedangkan kenampakan objek yang bergerak misalnya kapal. Liu dan Shu (2009) menjelaskan bahwa tracking dan monitoring kenampakan benda di lautan memerlukan citra satelit yang mempunyai resolusi tinggi dan resolusi temporal yang singkat. Kapal dan bangunan dapat dideteksi dengan menggunakan citra SAR resolusi tinggi. Secara umum kapal mempunyai sudut pantulan yang sangat efektif sehingga kapal mudah diamati sebagai titik terang pada citra SAR. Namun demikian, kadang-kadang kapal hampir tidak terlihat dan hanya tampak sebagai bangunan yang terlihat gelap.

Kenampakan objek di permukaan laut seperti kapal, bagan, platform migas dan lainnya secara umum mudah dipetakan menggunakan data citra satelit resolusi tinggi, seperti IKONOS, Quickbird, Wordview, Orb View dan lainnya. Akan tetapi, 
harga citra satelit tersebut relatif mahal. Penggunaan citra satelit resolusi menengah dan regional secara umum untuk pemetaan permukaan laut masih didominasi untuk pemetaan kondisi fisik dan kimia air laut. Kajiankajian tersebut diantaranya pemetaan suhu permukaan laut (Merchant dan Borgne, 2004; Lisan Yu, 2007; Minnet et al., 2002; Pichela et al., 2010), variasi salinitas dan densitasnya (Burrage et al., 2008), pemetaan sedimen (Volpe et al., 2011), pemetaan chlorofil dan blooming alga (Gonset et al., 2008), Pemetaan untuk identifikasi objek bergerak atau tetap di permukaan laut jarang dilakukan. Referensi tentang pemetaan tersebut biasanya dilakukan dengan menggunakan sensor aktif, seperti yang dilakukan oleh Liu dan Shu (2009).

Pada kajian ini dilakukan pemetaan objek di permukaan laut menggunakan citra Landsat 8 . Irons et al. (2012) menyatakan konsep dasar Landsat 8 (LDCM: Landsat Data Continuity Mission) adalah untuk mengumpulkan, mengarsipkan, pengolahan dan distribusi data sains secara konsisten dengan operasinya sistem satelit Landsat 7. Observatori Landsat 8 pada ketinggian $716 \mathrm{~km}$ dengan operasi hampir melingkar, dekat dengan kutub, orbit sunsynchronous $728 \mathrm{~km}$ Apogee, $704 \mathrm{~km}$ perigee, ketinggian $705 \mathrm{~km}$ pada equator). Siklus berulang selama 16 hari sekali dan melewati equator pada jam 10.00 pagi (+/- 15 menit) pada waktu lokal.

Hasil kajian ini diharapkan bermanfaat untuk perencanaan seismik sehingga estimasi ganti rugi dan peluang konflik dengan masyarakat menjadi berkurang dan kegiatan lainnya yang terkait. Manfaat lain yang yang mungkin adalah pencarian kapal laut yang hilang kontak ataupun mendeteksi potensi kapal pada kejadian illegal fishing. Pada kasus illegal fishing menurut Indomaritim (2011) dalam Prasetyo (2015) sedikitnya ada seribu kapal asing hilir mudik menangkap ikan secara illegal di Indonesia setiap tahunnya. Potensi kerugian kehilangan Penerimaan Negara Bukan Pajak (PNBP) sebesar 50 triliun pertahun.

\section{METODE}

Pada penelitian ini citra Landsat 8 yang digunakan adalah citra dengan perekaman tanggal 10 Mei 2014. Data tersebut bersumber dari http://glovis.usgs.gov. Pengolahan data Landsat dilakukan menggunakan software Envi 4.5. Pada pengolahan data ini dilakukan kalibrasi radiometrik. Chander et al. (2009) menjelaskan bahwa kalibrasi radiometrik dilakukan sebagai prasyarat untuk menghasilkan kualitas data geosains yang tinggi sehingga produk akhir yang dihasilkan lebih tinggi. Kalibrasi radiometrik merupakan proses yang menggunakan persamaan standar dengan mengkonversi angka digital dikalibrasi menjadi nilai reflektan satelit.

Rumus yang digunakan untuk mengolah data Landsat 8:

$\rho \lambda^{\prime}=M_{\rho} Q_{c a l}+A_{\rho}$

$P \lambda=\frac{\rho \lambda^{\prime}}{\cos \left(\theta_{S Z}\right)}=\frac{\rho \lambda^{\prime}}{\sin \left(\theta_{S E}\right)}$

Sumber: USGS, 2014

dimana:

$\rho \lambda^{\prime}=$ ToA Reflektansi, tanpa koreksi untuk sudut matahari

$M_{\rho} \quad=$ REFLECTANCE_MULT_BAND_x dimana $X$ adalah nomor Band

$A_{\rho} \quad=$ REFLECTANCE_ADD_BAND_x dimana $\mathrm{X}$ adalah nomor Band

Qcal = Nilai Digital (DN)

$\mathrm{P} \lambda=$ ToA reflektansi

$\theta_{S Z}=$ Sun Elevation

$\theta_{S E} \quad=$ Sudut zenith matahari

Berdasarkan pola pantulan (Asraf et al., 2011) dimana air mempunyai pola pantulan naik pada panjang gelombang hijau dan kemudian pantulan berkurang dan mendekati nol pada gelombang inframerah, sementara itu tanah mempunyai kecenderungan mempunyai pola pantulan yang terus naik ke arah inframerah tengah disajikan pada Gambar 1.

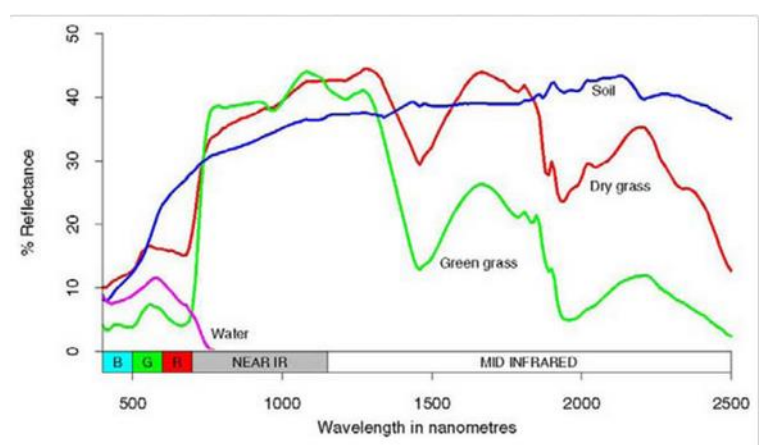

Gambar 1. Pola Pantulan Objek Utama di Permukaan Bumi. (Asraf et al., 2011)

Berdasarkan pola tersebut maka pada Landsat 8 untuk memetakan objek di permukaan laut dilakukan dengan menggunakan rumus NDVI dengan rumus:

NDVI $=($ NIR-RED $) /($ NIR+RED $)$

Dimana:

NDVI : Normalized Difference Vegetation Index

NIR : Near InfraRed

RED : visible light (merah)

Disamping itu dilakukan juga percobaan pemetaan objek di laut, khusus untuk Landsat 8 dilakukan uji coba dengan menggunakan rumus:

SWIRRED $=($ SWIR-RED $) /($ SWIR+RED $)$ 
Dimana:

SWIR : Short-Wave InfraRed

RED : visible light (merah)

\section{HASIL DAN PEMBAHASAN}

Pemetaan objek di permukaan laut berdasarkan perbandingan NIR dan RED dan SWIR dan RED ternyata mampu meningkatkan ketajaman objek yang ada di laut. Pada Gambar 2 secara visual terlihat bahwa pada komposisi band 653 (RGB) tidak semua kapal yang ada di pelabuhan Tanjung Emas Semarang dapat terlihat dengan jelas, tetapi pada hasil NDVI dan penisbahan saluran SWIR dan Red secara visual terlihat jelas kapal yang terdapat di pelabuhan tersebut disajikan pada Gambar 3. Bahkan tanggul yang membatasi pelabuhan (seperti jeti) terlihat dengan jelas sekali. Dari hasil tersebut terlihat bahwa Landsat 8 mempunyai kemampuan untuk mendeteksi kapal di laut. Pada Citra Landsat 8 hasil penisbahan saluran dengan rumus (SWIR-RED)/(SWIR+RED) terlihat lebih jelas dengan kapal yang lebih kontras disajikan pada Gambar 4.

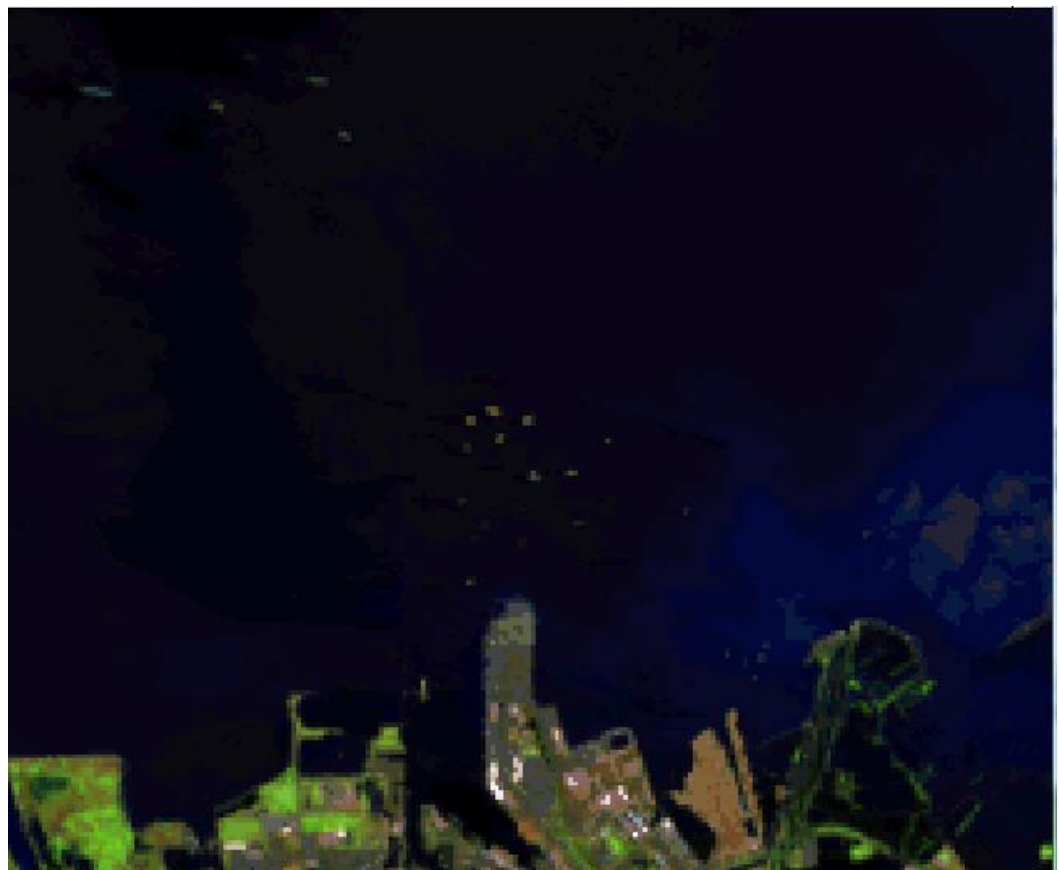

Gambar 2. Landsat 8653 RGB Wilayah Pelabuhan Semarang

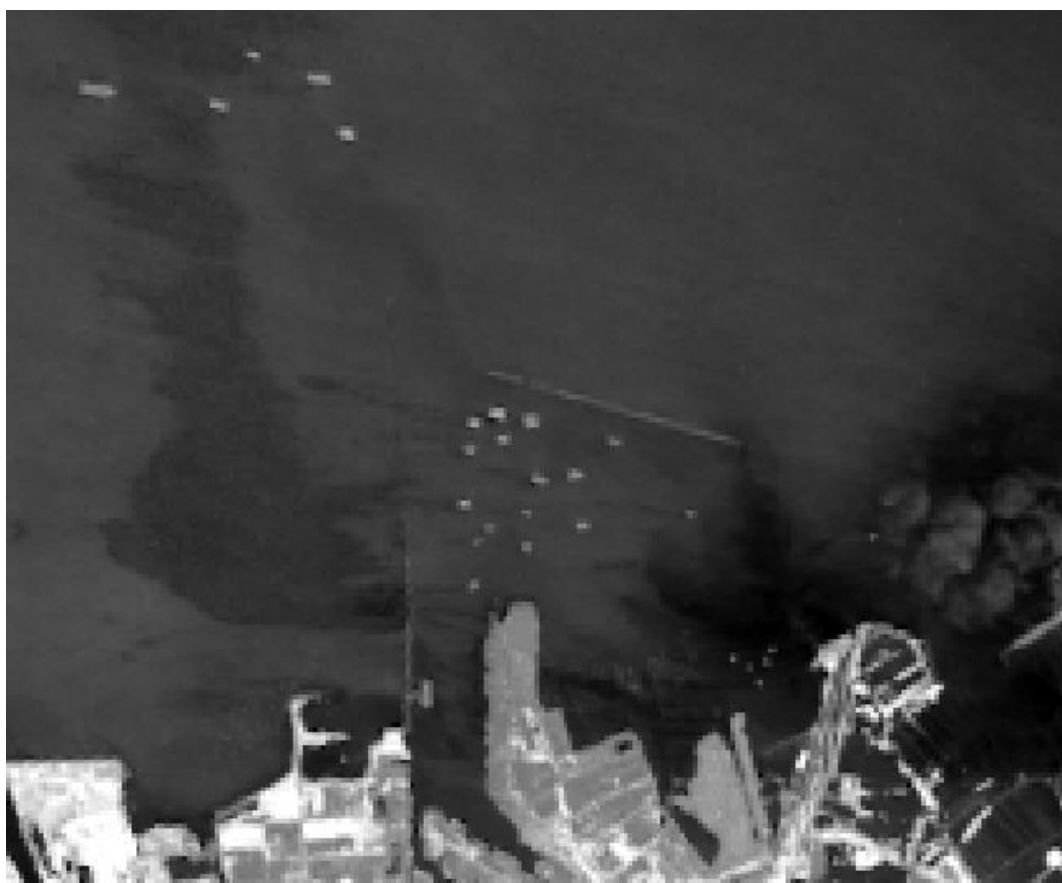

Gambar 3. Citra NDVI Landsat 8 Wilayah Pelabuhan Semarang. 


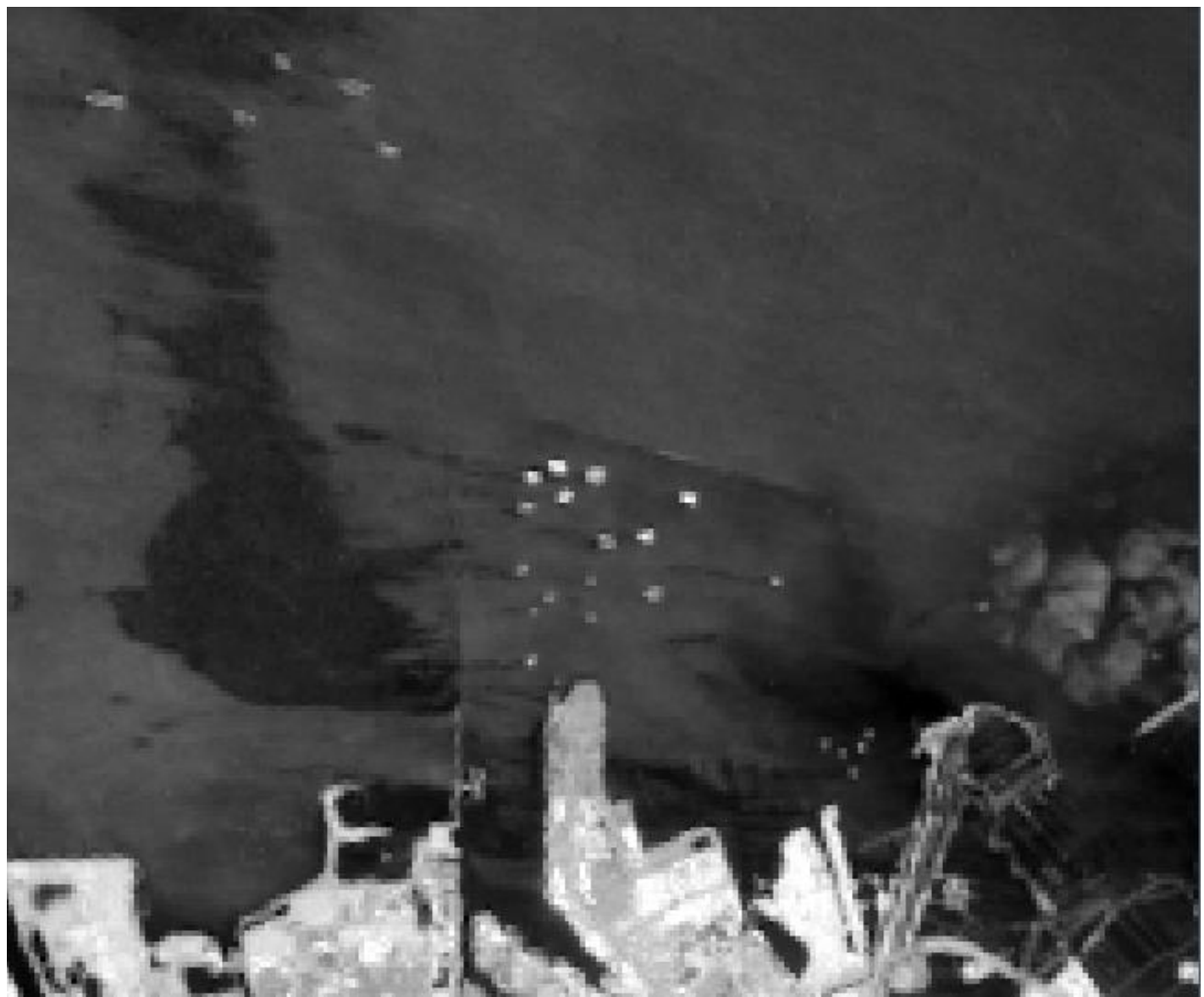

Gambar 4. Citra Hasil Penisbahan Saluran (SWIR-RED)/(SWIR +RED) Landsat 8 Wilayah Pelabuhan Semarang.

Citra hasil NDVI dan penisbahan saluran (SWIR-RED)/(SWIR+RED) pada Landsat 8 mampu memetakan kapal yang sedang bergerak dan bagan tancap. Pada kapal yang bergerak terlihat jelas arah gerakan kapal dengan ditandai adanya gelombang yang mengikuti di belakang kapal tersebut. Padahal pada komposisi band 653 (RBG) hal ini tidak dapat dilihat seperti yang disajikan pada Gambar 5.

Berdasarkan pola pantulan spektral seperti yang disajikan pada Gambar 1 objek kapal dan tanggul yang ada di laut terlihat lebih jelas karena bangunan ataupun tanah pada band Near Infra Red (NIR) dan Short Wave Infra Red (SWIR) bersifat lebih memantulkan gelombang elektromagnetik sehingga pantulan yang diterima satelit Landsat 8 lebih besar dibandingan dengan air pada band red yang semakin kecil dapat memantulkan balik gelombang elektromagnetik dan bahkan mempunyai kecenderungan untuk diserap. Hal ini menyebabkan perbandingan antara SWIR dengan red atau NIR dengan red akan dapat menonjolkan objek-objek non air di laut. Gelombang efek pergerakan kapal dapat terlihat juga diduga karena adanya efek ketidakteraturan morfologi air dan buih-buih gelombang yang berwarna putih.

Pemetaan bagan tancap dilakukan di perairan Jepara di sekitar Pulau Panjang di sebelah barat pantai Kartini. Bagan tancap merupakan metode penangkapan ikan yang banyak terdapat di Jepara. Bagan tancap terbuat dari rangkaian atau susunan bambu berbentuk persegi empat yang ditengahnya dipasang jaring. Kedalaman laut untuk pemasangan bagan tancap ini 7,5 m - 18 meter (Silitonga et al., 2014). Ukuran bangunan bagan tancap $13 \mathrm{~m} \times 13 \mathrm{~m}$ (Sudirman et al., 2013). Bagan tancap terkadang berukuran $7 \mathrm{~m} \times 7 \mathrm{~m}$ (kurnia dan Sudirman, 2014). Adapun detil bagan tancap dapat dilihat pada Gambar 6.

Berdasarkan ukuran bagan tancap, secara teori kenampakannya sulit terdeteksi oleh Landsat 8, karena hanya diwakili oleh 1 piksel pada Landsat tersebut. Pada komposisi 653 RGB bagan tancap tidak dapat terdeteksi oleh citra Landsat 8. Pada Citra Hasil NDVI dan Penisbahan Saluran (SWIR-RED)/(SWIR+RED) bagan dapat teridentifikasi dengan jelas dengan jumlah piksel 1 atau 2 piksel. Terdeteksinya bagan tancap ini diduga karena objek tersebut mampu memantulkan kembali panjang gelombang elektromagnetik ke satelit Landsat TM, sedangkan perairan sebagai objek disekitar bagan cenderung menyerap gelombang elektromagnetik sehingga dengan menggunakan NDVI dan penisbahan saluran bagan tancap menjadi objek dominan dibandingkan perairan disekitarnya. 


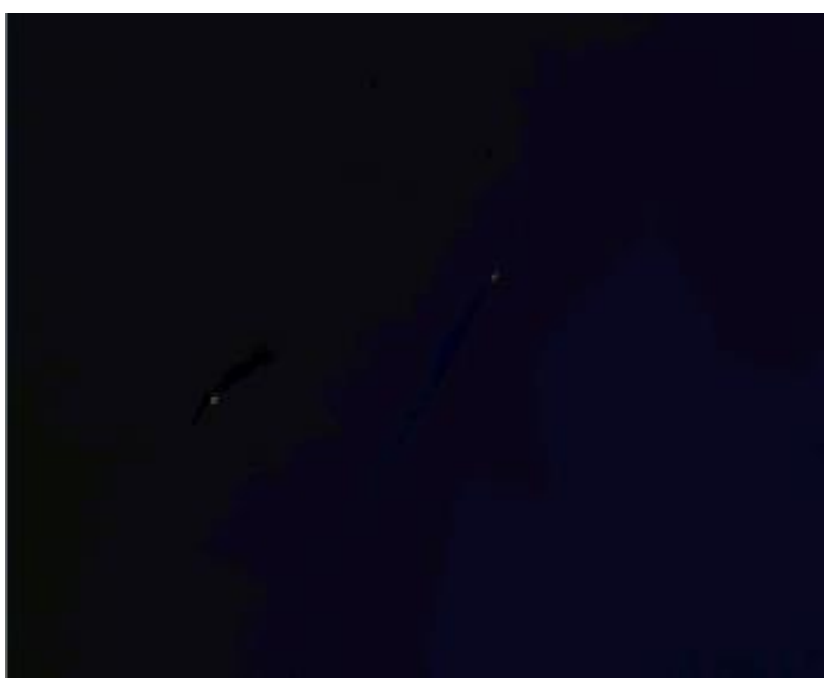

(a)

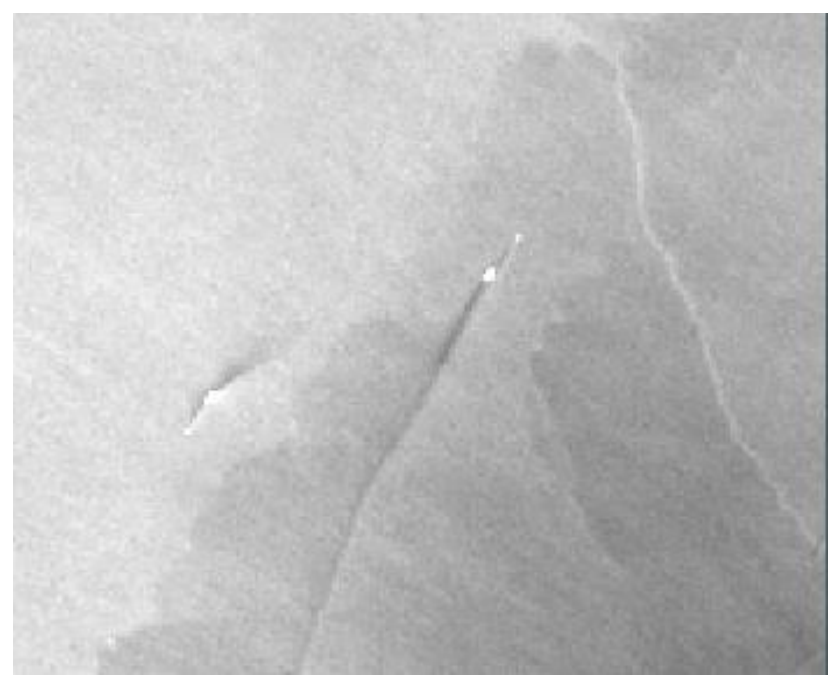

(b)

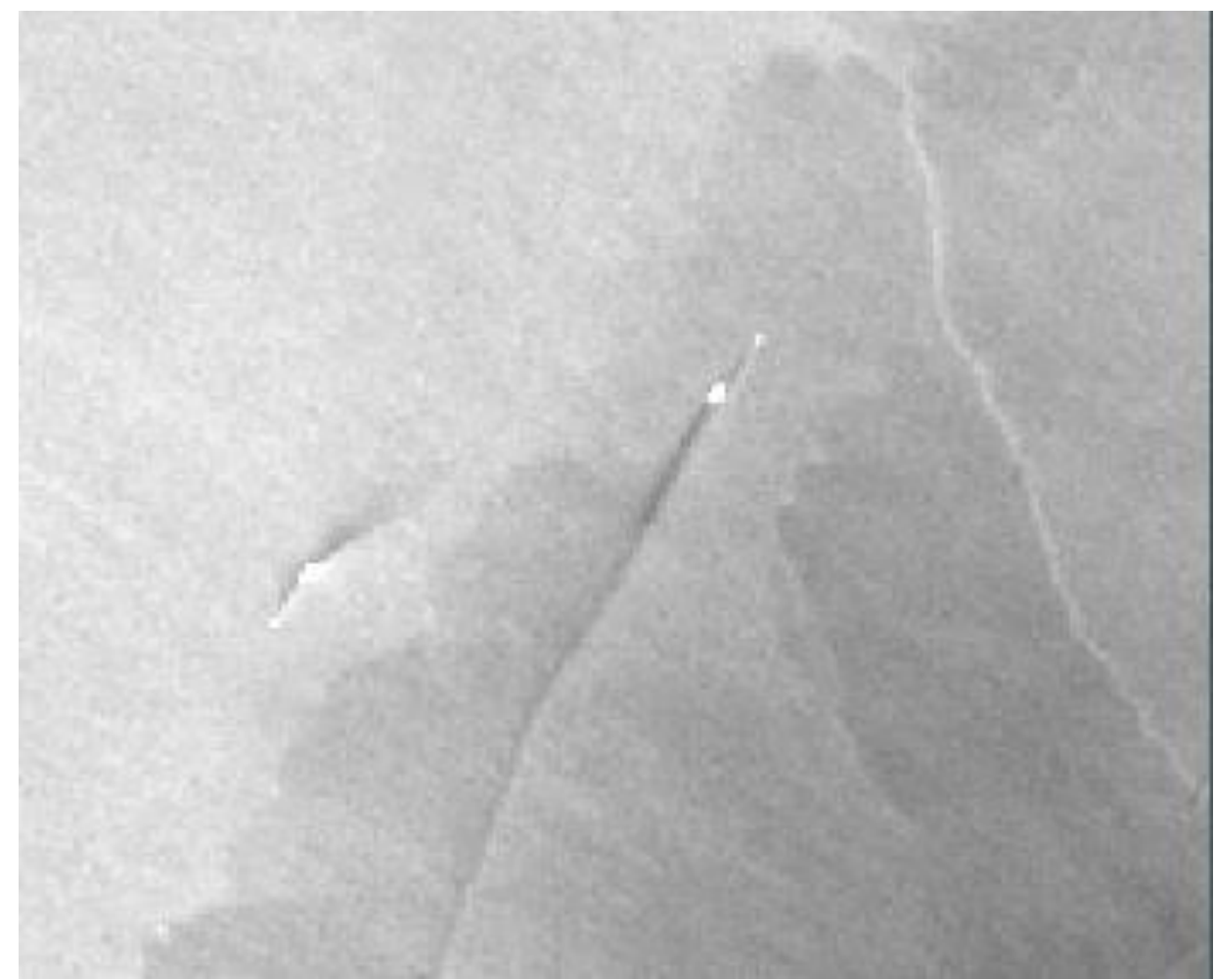

(c)

Gambar 5. Perbandingan Kenampakan Kapal yang Bergerak di Utara Delta Wulan Demak: (a) pada komposit 653 RGB; (b) Hasil NDVI; (c) Penisbahan Saluran (SWIR-RED)/(SWIR+RED).

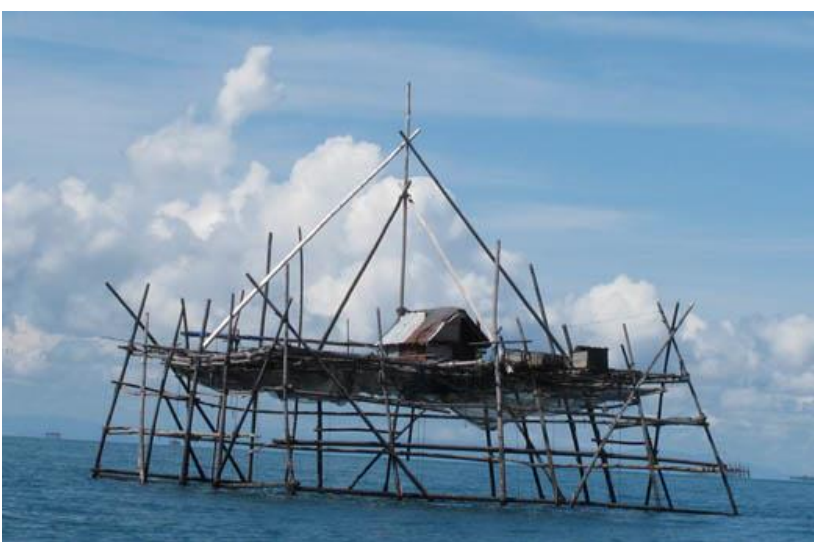

Sumber: Kurnia dan Sudirman (2014)

Gambar 6. Bentuk Bagan Tancap.
Interpretasi secara manual untuk bagan tancap yang berada di sekitar perairan Jepara diperoleh sekitar 61 bagan.

Adapun bagan tancap berdasarkan data Dinas Kelautan dan Perikanan Kabupaten Jepara (2012) terdapat kurang lebih 192 unit, yang tersebar di Kecamatan Mlonggo 26 unit, Jepara 36 unit, Tahunan 10 unit dan Kedung 116 unit (Silitonga et al., 2014). Adapun kenampakan bagan tancap pada hasil NDVI dan Penisbahan Saluran (SWIR-RED)/(SWIR+RED) dapat dilihat pada Gambar 7. 


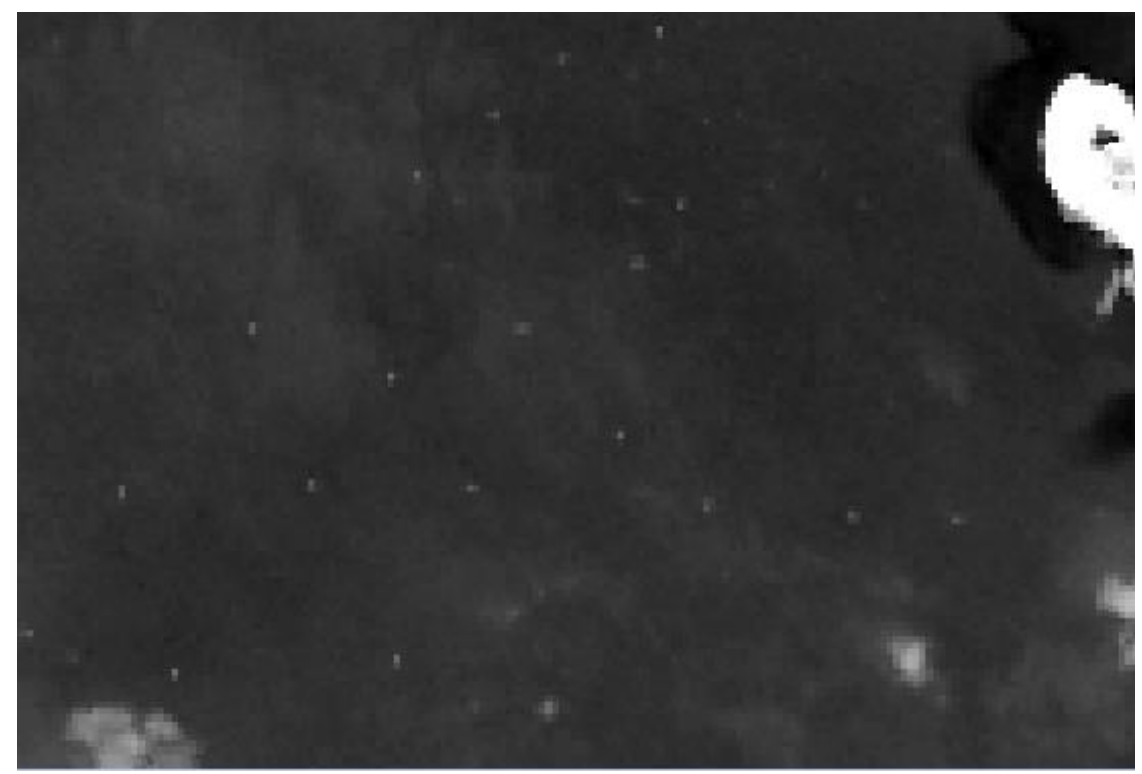

(a)

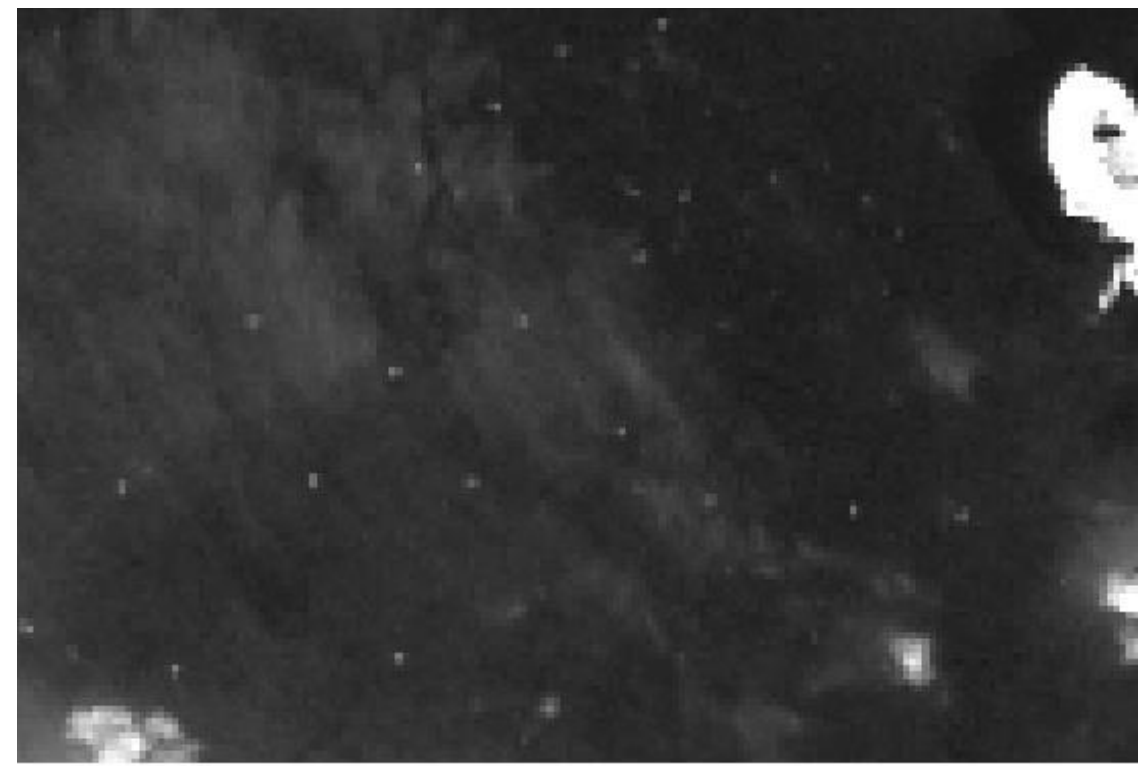

(b)

Gambar 7. Kenampakan Bagan Tancap di Perairan Jepara yang Teridentifikasi Sebagai Titik Piksel: (a) pada citra NDVI; (b) pada Citra Landsat 8 Hasil Penisbahan Saluran (SWIR-RED)/(SWIR+RED).

Berdasarkan hasil kajian ini landsat 8 mempunyai kemampuan untuk memetakan objek di permukaan laut dengan baik. Objek Kapal yang sedang sandar di pelabuhan maupun yang bergerak dapat teridentifikasi dengan baik. Bagan tancap yang mempunyai ukuran $7 \mathrm{~m}$ x $7 \mathrm{~m}$ sampai $12 \mathrm{~m}$ x $12 \mathrm{~m}$ dapat pula teridentifikasi menggunakan NDVI dan penisbahan saluran (SWIR-RED)/(SWIR+RED). Teridentifikasinya objek-objek di laut akan bermanfaat untuk berbagai perencanaan dan pencarian kapal yang hilang kontak. Pada pencarian kapal yang hilang kontak bisa dimungkinkan apabila kejadiannya bersamaan pada saat perekaman data di lokasi terakhir kontak atau monitoring pergerakan kapal laut di daerah rawan illegal fishing. Pada perencanaan misalnya di bidang migas untuk kegiatan seismik. Kegiatan seismik dalam rangka pencarian migas pada perairan laut terkadang terkendala karena kurang adanya informasi adanya bagan di laut sehingga sering terjadi konflik dengan nelayan bagan. Melalui pemetaan awal identifikasi bagan tancap akan memudahkan dalam perencanaan jalur seismik. Pengambilan keputusan untuk ganti rugi dalam rangka pembongkaran sementara bagan tancap atau menggeser lokasi akan lebih mudah. Konflik akibat seismik pernah terjadi di Balikpapan. Konflik tersebut terjadi dimana perusahan migas multinasional memotong puluhan rumpon karena mengganggu proses seismik (Kinseng, 2007).

\section{KESIMPULAN}

Landsat 8 mempunyai kemampuan untuk memetakan objek-objek di laut dengan baik. 
Kemampuan tersebut dilakukan melalui NDVI dan penisbahan saluran (SWIR-RED)/(SWIR+RED). Objek-objek tersebut berupa kapal yang sedang sandar di pelabuhan, kapal yang sedang bergerak yang ditandai dengan adanya buih gelombang di belakangnya dan bagan tancap. Pada bagan tancap dapat diidentifikasi dengan adanya 1 atau 2 piksel yang mempunyai brightness dan kontras yang berbeda dengan sekitarnya sehingga dapat terlihat dengan jelas. Kemampuan ini dapat dimanfaatkan secara optimal untuk perencanaan kegiatan di bidang migas terutama seismik dan peluang mencari kapal yang hilang kontak ataupun monitoring daerah rawan illegal fishing.

\section{UCAPAN TERIMA KASIH}

Pada kesempatan ini penulis mengucapkan terima kasih kepada Pimpinan PUSPICS, Universitas Gadjah Mada beserta stafnya yang telah memberikan pelatihan penginderaan jauh.

\section{DAFTAR PUSTAKA}

Ashraf, M.A., M.J. Maah and I. Yusoff. (2011). Introduction to Remote Sensing of Biomass. "Biomass and Remote Sensing of Biomass", book edited by Islam Atazadeh, ISBN 978-953-307-4900, Published: September 6, 2011 under CC BY-NCSA 3.0 license.

Burrage, D., J. Wesson, and J. Miller. (2008) Deriving Sea Surface Salinity and Density Variations From Satellite and Aircraft Microwave Radiometer. IEEE TRANSACTIONS ON GOSCIENCE AND REMOTE SENSING. VOL. 46. NO. 3, MARCH 2008765. http://www.dtic.mil/dtic/tr/fulltext/u2/a482176.pd $f$

Chander, G., B. Markham and D.L. Helder. (2009). Summary of current radiometric calibration coefficients for Landsat MSS, TM, ETM+, and EO-1 ALI sensors. Remote Sensing of Environment. http://landsathandbook.gsfc.nasa.gov/pdfs/ Landsat_Calibration _ Summary_RSE.pdf

Gons, H.J., M. T. Auer and S.W. Effler. (2008). MERIS satellite chlorophyll mapping of oligotrophic and eutrophic waters in the Laurentian Great Lakes. Remote Sensing of Environment Journal. Volume 112 , Issue 11,15 November 2008, Pages 40984106. Applications of Remote Sensing to Monitoring Freshwater and Estuarine Systems. http://www.sciencedirect.com/science/article/pii/S 0034425708002083

Irons, J.R., J.L. Dwyer and J.A. Barsi. (2012). The next Landsat satellite: The Landsat Data Continuity Mission. Remote Sensing of Environment journal. www.elsevier.com/locate/rse.

Kinseng, R.A. (2007). Konflik-Konflik Sumberdaya Alam di Kalangan Nelayan Indonesia. Journal Transdisiplin Sosiologi, Komunikasi, dan Ekologi Manusia. Page 87-104. ISSN : 1978-4333. Vol 01. No. 1 didownload tanggal 1 Juni 2015. http://journal.ipb.ac.id/index.php/sodality/article/v iew File/5936/4613

Kurnia M. dan Sudirman. (2014). Penerapan Teknologi Hidroakustik pada Perikanan Bagan Tancap.
Fakultas Ilmu Kelautan dan Perikanan. Universitas Hasanuddin.

http://repository.unhas.ac.id/bitstream/handle/12

3456789 /11406/Fullpaper-ISFM 2014_ M.KurniaUnhas.pdf?sequence $=1$

Lisan Yu. (2007). Sea surface exchanges of momentum, heat, and freshwater determined by satellite remote sensing. In: J. Steele, S. Thorpe, and $K$. Turekian (eds.), Encyclopedia of Ocean Sciences, First Online Update. Academic Press, London, UK. Accepted; October, 2007. http://oaflux.whoi.edu/pdfs/Yu-SatFluxes.pdf

Liu, A.K. and M.K. Hsu. (2009). Deriving Ocean Surface Drift Using Multiple Sars Sensors. Remote Sensing Journal. www.mdpi.com/journal/remotesensing

Merchant, C.J. and P. L. Borgne. (2004). Retrieval of Sea Surface Temperature from Space, Based on Modeling of Infrared Radiative Transfer: Capabilities and Limitations. American Meteorogical Society Journals Online.http://journals.ametsoc.org/doi/abs/10.117 5/JTECH1667.1

Minnett, P. J., .H. Evans, E.J. Kearns and O.B. Brown. (2002). Sea-surface temperature measured by the Moderate Resolution Imaging Spectroradiometer (MODIS). Rosenstiel School of Marine \& Atmospheric Science. University of Miami. IEEE Journal.

https://cimss.ssec.wisc.edu/dbs/China2011/Day2/ Lectures /MODIS_MOD28_SST_Reference.pdf.

Prasetyo, k. C. (2015). Indonesia, Asean dan Pemberantasan Illegal Fishing. http://www.academia.edu/7392029.INDONESIA_A SEAN_DAN_PEMBERANTASAN_ILEGAL_FISHING

Pichela, W., E. Maturia, P. Clemente-Colóna and J. Sappera. (2010). Deriving the operational nonlinear multichannel sea surface temperature algorithm coefficients for NOAA-15 AVHRR/3. International Journal of Remote Sensing. Pages 699 - 704. Volume 22, Issue4, 2001.

http://www.tandfonline.com/doi/abs/10.1080/014311 60010013793?journalCode $=$ tres20\#.VMWH89KsU-g

Silitonga, M.F., Pramonowibowo dan A. Hartoko. (2014). Analisis Sebaran Bagan Tancap dan hasil Tangkapan di Perairan Bandengan Jepara, Jawa Tengah. Journal of Fisheries Resources Utilization Management and Technology, Volume 3. No 2.Hal. 77-84. http://www.ejournals1.undip.ac.id/index.php.jfrumt.

Sudirman, Najamuddin dan M. Palo. (2013). Efektifitas Penggunaan Berbagai Jenis lampu Listrik untuk Menarik Perhatian Ikan Pelagis Kecil pada Bagan Tancap. Journal Penelitian Perikanan Indonesia. Vol. 19. No. 3 hal. 157-165

USGS. (2014). Using the USGS Landsat 8 Product. Didownload tanggal 31 November 2014. http://landsat.usgs.gov/Landsat8_Using_Product.p hp.

Volpe, V., S. Silvestri \& M. Marani. (2011). Remote Sensing Retrieval of Suspended Sediment contentration in Shallow Waters. Remote Sensing of Environmental Journal page 44-54. Elsevier.

www.elsevier.com/locate/rse.

http://glovis.usgs.gov. 
Halaman ini sengaja dikosongkan 